\title{
Morphological Complexity as a Floral Signal: From Perception by Insect Pollinators to Co-Evolutionary Implications
}

\author{
Shivani Krishna and Tamar Keasar* \\ Department of Biology and Environment, Faculty of Natural Sciences, University of Haifa, Oranim, Tivon 36006, \\ Israel; sshivani@campus.haifa.ac.il \\ * Correspondence: tkeasar@research.haifa.ac.il; Tel.: +972-52-871-8860
}

Received: 3 May 2018; Accepted: 4 June 2018; Published: 6 June 2018

\begin{abstract}
Morphologically complex flowers are characterized by bilateral symmetry, tube-like shapes, deep corolla tubes, fused petals, and/or poricidal anthers, all of which constrain the access of insect visitors to floral nectar and pollen rewards. Only a subset of potential pollinators, mainly large bees, learn to successfully forage on such flowers. Thus, complexity may comprise a morphological filter that restricts the range of visitors and thereby increases food intake for successful foragers. Such pollinator specialization, in turn, promotes flower constancy and reduces cross-species pollen transfer, providing fitness benefits to plants with complex flowers. Since visual signals associated with floral morphological complexity are generally honest (i.e., indicate food rewards), pollinators need to perceive and process them. Physiological studies show that bees detect distant flowers through long-wavelength sensitive photoreceptors. Bees effectively perceive complex shapes and learn the positions of contours based on their spatial frequencies. Complex flowers require long handling times by naive visitors, and become highly profitable only for experienced foragers. To explore possible pathways towards the evolution of floral complexity, we discuss cognitive mechanisms that potentially allow insects to persist on complex flowers despite low initial foraging gains, suggest experiments to test these mechanisms, and speculate on their adaptive value.
\end{abstract}

Keywords: associative learning; floral tube; perception; pollinator specialization; reward signal; symmetry

\section{Introduction}

Pollination, a major plant-insect interaction, is an important selective force that drives (combined with other forces) the evolution of flower traits. Pollinators perceive diverse floral signals and cues and modify their foraging behavior in response, thereby affecting both their own foraging success and the plants' reproductive prospects. Here, we focus on a suite of features involved in producing morphologically complex flowers, and review their role as signals in interactions with insect pollinators.

\section{What Are Morphologically Complex Flowers?}

Complex flowers are structurally defined as having floral parts of many different types, which often fuse to form elaborate structures [1]. Functionally, complex flowers possess morphological features that restrict the access of insect visitors to their nectar and pollen rewards. These include bilateral symmetry (zygomorphy, see Table 1 for definitions of terms), fusion of petals, corollas that face sideways or downwards, long and/or narrow floral tubes, and concealed nectaries [2-8]. 
Table 1. Glossary of terms used in this review.

\begin{tabular}{|c|c|}
\hline Term & Definition \\
\hline Achromatic stimuli & Visual stimuli that vary only in the total intensity of reflected light. \\
\hline Actinomorphy & Two or more planes of symmetry; radial symmetry. \\
\hline Chromatic stimuli & $\begin{array}{l}\text { Visual stimuli that vary only in the spectral (wavelength) composition of the reflected } \\
\text { light (color). }\end{array}$ \\
\hline Color distance & $\begin{array}{l}\text { A metric indicative of perceptual color difference between two stimuli in animal } \\
\text { color spaces (graphical models based on photoreceptor properties and sensitivities). }\end{array}$ \\
\hline Color-opponency & $\begin{array}{l}\text { Combination of differential neuronal outputs of color-sensitive photoreceptors to } \\
\text { create a signal in the processing of color. }\end{array}$ \\
\hline Floral integration & Covariation in flower parts. \\
\hline Flower constancy & $\begin{array}{l}\text { Tendency for an individual pollinator to visit flowers of a single species within a } \\
\text { foraging bout. }\end{array}$ \\
\hline Geitonogamy & $\begin{array}{l}\text { A type of self-pollination, in which a flower is fertilized by pollen from another } \\
\text { flower of the same individual plant. }\end{array}$ \\
\hline Nectary & Specialized cells that are usually part of a flower, which secrete sugary fluids. \\
\hline Photopigment & $\begin{array}{l}\text { A chemical that undergoes a chemical change when exposed to light. In vision, these } \\
\text { are primarily the visual pigments or other opsin-based molecules. }\end{array}$ \\
\hline Poricidal anthers & Anthers packed with loose pollen grains, dehiscing by a pore at one end of the thecae. \\
\hline Trichromacy & A color-vision system based on three classes of color receptors. \\
\hline Visual acuity & $\begin{array}{l}\text { The minimum angular separation between two objects in the visual field that are } \\
\text { perceived as distinct, at a given distance from the viewer. }\end{array}$ \\
\hline Visual field & The limits of the space around the eyes from which visual information is obtained. \\
\hline Zygomorphy & $\begin{array}{l}\text { A single plane of symmetry; bilateral symmetry; one half of an object mirrors the } \\
\text { other half. }\end{array}$ \\
\hline
\end{tabular}

Fusion of petals, that is, sympetaly, resulted in the evolution of long tubed flowers in the lineages Ranunculales, Saxifragales, Ericales, and Dioscorales (Figure 1a) $[9,10]$. Some of these sympetalous flowers and a few others with polypetaly evolved further complexity in the form of spurs. These are long outgrowths that emerge from the corolla base and house nectar. Families with such spurred flowers include Tropaeolaceae, Balsaminaceae, and Orchidaceae (Figure 1b,c). A phenotypic fit between the proboscis of insects and the length of the corolla tube or spur in such flowers is critical for pollination. Apart from phenotypic fit, morphologically complex flowers, such as those with 'keel' flowers, require the use of mechanical force to access the nectar and pollen rewards. Such keel flowers are common in several plant families, most prominently in the Fabaceae (Figure 1d) [11,12]. Another class of complexity includes the lip forms found in Orchidaceae, Lamiaceae, Proteaceae, and Iridaceae (Figure 1e,f). Lip forms display a variety of constructions such as locked entrances in Phlomis and Iris and those with reduced lower lips in Leonotis where pollen is precisely deposited on the dorsal side of the pollinators [12-14]. Overall, zygomorphic flowers exhibit stronger floral integration compared to actinomorphic flowers, with concerted variation in structure and number of reproductive parts together with their perianth $[15,16]$. Table 2 summarizes the main features of floral complexity in different plant families and Figure 1 shows some examples of complex flowers. 

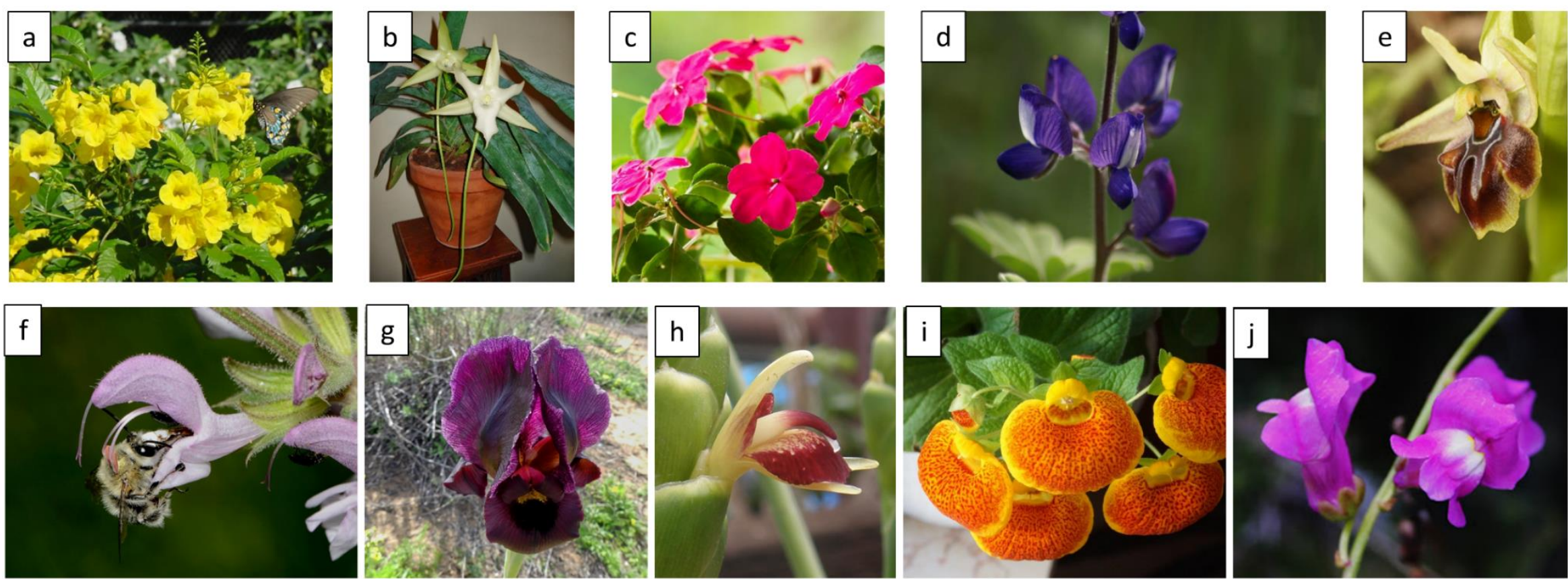

Figure 1. Examples of complex morphologies of flowers. (a) Tecoma stans (Bignoniaceae); (b) Angaecum sesquipedale (Orchidaceae); (c) Impatiens balsamina (Balsaminaceae); (d) Lupinus pilosus (Fabaceae); (e) Ophrys alasiatica (Orchidaceae); (f) Salvia hierosolymitana (Lamiaceae); (g) Iris atropurpurea (Iridaceae); (h) Zingiber officinale (Zingiberaceae); (i) Calceolaria crenatiflora (Calceolariaceae); (j) Antirrhinum majus (Plantaginaceae). Photographers: (a) Calvin Finch; (b) Karole Schon; (d,i) Judith Marcus; (e) Michael Pettemerides; (f) Gideon Pisanty; (g) Ada Knossow; (h) Alastair Culham; (j) George Konstantinu.

Table 2. Features of morphological complexity in flowers of selected plant families.

\begin{tabular}{llll}
\hline Family & Floral Morphology & Pollinators & Examples (Genera) \\
\hline Acanthaceae & $\begin{array}{l}\text { Fused corolla lobes, usually bilabiate (upper lip suppressed and } \\
\text { larger lower lip in some species) }\end{array}$ & Bees, hummingbirds, flies, moths & Acanthus, Justicia \\
\hline Balsaminaceae & $\begin{array}{l}\text { Four petals combined in pairs and one upper petal, usually 3-5 } \\
\text { sepals, one of which forms a long tube called spur }\end{array}$ & Bees & Impatiens, Hydrocera \\
\hline
\end{tabular}


Table 2. Cont.

\begin{tabular}{|c|c|c|c|}
\hline Family & Floral Morphology & Pollinators & Examples (Genera) \\
\hline Bignoniaceae & $\begin{array}{l}\text { Fused corolla lobes (usually five), bilabiate, large and showy, with } \\
\text { wider upper part }\end{array}$ & Bees, bats, hummingbirds & Tecoma, Incarvillea, Spathodea \\
\hline Boraginaceae & $\begin{array}{l}\text { Five petals fused, sometimes lobed, forming a tube or funnel shape } \\
\text { with infoldings or scales }\end{array}$ & Bees, butterflies, hummingbirds & Onosma, Heliotropium \\
\hline Cannaceae & $\begin{array}{l}\text { Corolla three-lobed, forming a tube together with stamen and } \\
\text { staminodes }\end{array}$ & Bees, birds & Canna \\
\hline Caprifoliaceae & Five fused corolla lobes forming a tube or funnel shape & Bees, butterflies, moths, hummingbirds & Lonicera, Abelia \\
\hline Fabaceae & $\begin{array}{l}\text { Flag is formed by single median petal and the keel is composed of } \\
\text { two petals (in lower lateral position) which secondarily join into a } \\
\text { common boat-shaped petal }\end{array}$ & Bees & Lupinus, Lotus \\
\hline Goodeniaceae & $\begin{array}{l}\text { Five unified corolla lobes either uni-or bilabiate, stamens form a } \\
\text { tube-like structure }\end{array}$ & Bees & Dampiera, Scaevola \\
\hline Iridaceae & $\begin{array}{l}\text { Corolla is formed by three inner and three outer segments, free or } \\
\text { united }\end{array}$ & Bees, birds & Iris, Crocosmia \\
\hline Lamiaceae & $\begin{array}{l}4-5 \text { corolla lobes often reduced to } 2-3 \text {, with two lips. Upper lip is } \\
\text { two-lobed and lower lip is three-lobed. Lower lip occasionally } \\
\text { hooded or concave }\end{array}$ & Bees, hummingbirds, flies & Salvia, Plectranthus, Lamium \\
\hline Moringaceae & $\begin{array}{l}\text { Five petals, unequal and overlapping; petaloid sepal; resemble } \\
\text { inverted keel flowers of Fabaceae }\end{array}$ & Bees & Moringa \\
\hline Orchidaceae & $\begin{array}{l}\text { Three petaloid sepals and three petals, variable in shape and color, } \\
\text { sometimes spurred or with enlarged sac-like tepal. The inner } \\
\text { median, anterior tepal is enlarged and is called the labellum }\end{array}$ & Bees & Ophrys, Catasetum \\
\hline Proteaceae & $\begin{array}{l}\text { Four slender petaloid sepals, distinct or united, forming a tubular } \\
\text { structure, petals usually absent }\end{array}$ & Birds, beetles & Grevillea, Conospermum \\
\hline Resedaceae & $\begin{array}{l}\text { Clawed petals, fringed, bifid, vary in number from } 2 \text { to } 8, \\
\text { innermost petal is large and outer ones are smaller }\end{array}$ & Bees & Reseda \\
\hline Scrophulariaceae & $\begin{array}{l}\text { Bell-shaped corollas with variations including narrow corolla tube, } \\
\text { spurs, keel petal }\end{array}$ & Bees, hummingbirds & Digitalis, Linaria, Antirrhinum \\
\hline Valerianaceae & $\begin{array}{l}\text { Five overlapping corolla lobes, sometimes fused, basal nectar-filled } \\
\text { spur }\end{array}$ & Butterflies & Centranthus \\
\hline Vochysiaceae & Five overlapping corolla lobes, fused, basal nectar filled spur & Bees, butterflies & Vochysia, Callisthene \\
\hline Zingiberaceae & $\begin{array}{l}\text { Tubular corolla with three lobes, colored petaloid labellum derived } \\
\text { from staminodes }\end{array}$ & Bees & Mantisia, Zingiber \\
\hline
\end{tabular}


Poricidal anthers need to be sonicated ("buzzed") by insect visitors for the pollen to be released. Since not all pollinators are capable of buzzing [17], and since effective buzzing requires practice [18], poricidal anthers can be regarded as an additional characteristic of morphological complexity. Complex flowers often also exhibit modifications of reproductive structures, such as syncarpy (united carpels within the ovaries), increased ovule numbers, and oligostemony ( $\leq 2$ whorls of stamens) [19]. Since these traits are not considered signals for pollinators, we will not discuss them further here. Morphological complexity of flowers is distinct from signal complexity, which often entails a combination of several modalities (such as color and odor) in floral advertising, and which has been discussed elsewhere [20,21].

Rewardless flowers have evolved in about 7500 species, and $85 \%$ of them belong to the family Orchidaceae [22]. While most of the orchid species are zygomorphic [23], their floral morphologies have probably been molded by diverse selection pressures. This is mainly due to the deceptive strategies involved, which range from mimicking a sympatric rewarding species to mimicry of female insects. Mimicry of complex morphologies is potentially a fine solution for enhancing trickery because visitors to the deceptive flowers cannot tell from a distance that these flowers lack reward. It has been proposed that insects visit complex deceptive flowers (and thereby select for them) as long as their associated cost in foraging efficiency is sufficiently low [24]. This idea has not been experimentally tested yet.

The structural features that make flowers complex may be directly perceived by pollinators and thus serve as visual signals or cues. Complexity could also potentially be advertised by other, correlated, floral traits that are not necessarily parts of any specific floral organ. For example, long floral tubes (a structural feature) are correlated with blue corolla color $[25,26]$ and low achromatic contrast between corolla and background (non-structural signals) [25] in Mediterranean and temperate grassland plants. Similarly, violet corolla color correlates with the presence of a corolla tube within the crucifers of Israel [27]. The blue and violet corollas are attractive to bees [26]. In Aquilegia, flower traits related to complexity (length of the nectar spur and flower orientation) correlate with flower and spur color. A quantitative trait locus (QTL) analysis of these traits suggests that they are under shared genetic control [28]. An example for a non-visual and non-structural trait that indicates floral complexity is that of Polemonium viscosum flowers, which have two scent morphs (sweet and skunky). Each scent morph is associated with a different length of the floral tube [29].

\section{How Common Are Complex Flowers?}

Floral complexity is widespread, both evolutionarily and biogeographically. Buzz pollination occurs in more than 65 angiosperm families [30,31]. Zygomorphic flowers were recorded in 83 angiosperm families [5] and are known to have evolved independently from actinomorphic flowers more than 25 different times during the late cretaceous period [32-35].

As morphologically complex flowers are associated with more specialized pollination (see Section 4), increased likelihood of character displacement followed by higher diversification rates have been predicted in such taxa [35-39]. In line with this prediction, some of the most species-rich angiosperm families such as the Fabaceae, Lamiaceae, and Orchidaceae have complex flowers. Furthermore, sister-group analyses of zygomorphic lineages revealed higher species richness in comparison with actinomorphic lineages [36,40]. Of the 57 zygomorphic families examined by Sargent [36], 54.3\% have a widespread distribution; 28\% occur predominantly in Africa, Europe, and Asia; and 15.7\% in the North and South Americas. However, this correlation could reflect the fact that wide geographical distribution, particularly in the tropics, also promotes speciation and diversification of plants. Characteristics such as herbaceous habit, hermaphroditism, and absence of fleshy fruits were also associated (albeit weakly) with zygomorphy. These traits may also act in concert with floral complexity to promote speciation $[5,40]$. 


\section{The Role of Morphological Complexity in Specialization of Plant-Pollinator Interactions}

It has been repeatedly hypothesized that only a subset of all pollinators are capable of reaching the nectar and pollen rewards in morphologically complex flowers, whereas simple flowers are accessible to a wide range of visitor species. This was predicted to reduce the number of pollinator species that forage on complex flowers [41], and potentially also visitation rates [42]. The evidence for these predictions from observational studies is mixed. The length and width of the nectar tube were found to act as filters for nectar foragers, by barring visitors whose proboscises are shorter or wider than the tube. Thus, flowers with long and narrow corolla tubes were visited by fewer pollinator species than short-tube flowers [43]. Similarly, simple flowers were visited by a more diverse insect assemblage than complex flowers in four Himalayan mountain plant communities [41]. In European alpine communities, higher local foraging specialization of bees (i.e., fewer plant species visited at an observation site) correlated with high frequency of visits to long-tubed flowers. However, this correlation was weaker in flies and non-existent in Lepidoptera [44], possibly because their flexible proboscis allows access to flowers of many shapes. In addition, a study that classified flowers of 1403 plant species as either "open" or "closed", based on corolla morphology, did not find a wider range of visitors to open flowers than to closed ones [45]. Similarly, the number of visitor species was not affected by floral morphology in species-rich pollination networks in the Peruvian Andes [46].

Similar conflicting findings concern the relationship between floral complexity and visitation rates. As predicted, tubular flowers received fewer visits than open ones in plant communities from several floristic regions [42,47]. Long-tubed artificial flowers received fewer bumblebee visits than short-tubed flowers in laboratory experiments $[7,48]$. Two other studies, on the other hand, found different trends: in a Norwegian grassland, actinomorphic open flowers received more visits by flies than zygomorphic closed flowers, whereas visit rates by bumblebees were not influenced by flower morphology [49]. Salvia nipponica flowers, which were manipulated in the field for reduced complexity, received visits by bumblebees at the same rate as intact flowers [50].

In situations where complex flowers attract fewer pollinator species and receive fewer visits than simple flowers, their abundance and spatial distribution may be affected. As a test of this hypothesis, morphological complexity of flowers within 427 plant species from the Greek flora was examined in the context of vulnerability of extinction risk. Complex morphological shapes such as tube, flag, gullet, and trap with bilateral symmetries were found to be relatively more vulnerable compared to the open shapes with radial symmetry. This could be due to insufficient pollination experienced by plants with complex flowers [8]. In agreement with this interpretation, high-elevation flower communities in the Switzerland and Italy (where pollinator diversity is low and bees are scarce) have mostly simple morphologies. Lower-altitude communities with high bee abundance have more diverse morphologies and higher proportions of complex flowers [51,52].

\section{Benefits of Complex Flower Shapes: The Plant Perspective}

What selective advantages maintain complex flowers in plant communities, even though they attract fewer pollinators? It has been proposed that insect species that can handle complex flowers are also highly effective pollinators, and thus increase the plants' pollination success. In particular, the "filtering" of pollinators by their ability to handle floral complexity was hypothesized to enhance pollinator constancy. Highly specialized pollinators were proposed to mainly exploit complex flowers of a few species, rather than shifting among the many species with simple morphologies. This could reduce the costs of inter-specific pollen transfer, providing a selective benefit to floral complexity for the plants [53].

Tests of the effects of floral complexity on flower constancy yielded equivocal results. In one field study, plants with complex flowers shared fewer insect visitors with a simple-flowered focal plant (Euphorbia esula), compared with other simple-flowered species in the same plant community. In addition, fewer pollen grains of the focal species were deposited on the stigmas of complex flowers as compared to simple flowers, confirming higher conspecific pollen transfer in species with complex 
flowers [54]. Other studies, however, did not show the predicted pattern: in one of them, the cumulative (season-long) deposition of heterospecific pollen was higher on the stigmas of zygomorphic flowers than on actinomorphic ones [55]. In another, there was no effect of floral symmetry on the frequency of pollen transfer among 19 plant species across three plant communities [56]. A laboratory study characterized flower constancy by recording the visit sequences of bumblebees on floral arrays that contained pairwise combinations of four flower species. Two of the species were morphologically complex and the remaining two were simple. The bees were most constant to one of the complex species, but least constant to the other [57].

A related putative benefit of complex flowers for plants is a reduced risk of geitonogamous selfing. As floral handling times are increased, the relative costs of travel time diminish in terms of foraging efficiency. This may induce visitors to make longer flights, resulting in fewer successive visits per plant. Bumblebees that foraged on manipulated Salvia nipponica flowers, in which the access to the nectaries was experimentally simplified, indeed shifted less often among plants than bees that visited intact flowers [50].

Bilateral symmetry was also suggested to promote more consistent entry by pollinators into the flower. This could increase the contact of floral sex organs with the insect's body and improve the plant's reproductive prospects. The angle of entry by bumblebees into dissymmetric artificial flowers was in fact more consistent than when they entered radially symmetric flowers [58].

\section{Benefits of Complex Flower Shapes: The Pollinator Perspective. Is Floral Complexity an Honest Signal of Reward?}

From the pollinators' point of view, floral complexity has been suggested to signal high foraging rewards. The rationale for this expectation is twofold: at the evolutionary level, since complex flowers can be pollinated by only a few specialized insects, they would be selected for higher nectar and pollen production rates $[59,60]$. At the proximate level, complex flowers receive fewer foraging visits, and thus are expected to have higher standing crops of food rewards because of reduced consumption by insects. Consistent with these predictions, nectar production rates correlated positively with flower tube depth across eight species of Ericaceae [61], among hundreds of hummingbird-pollinated plants [62,63], and among 76 Mediterranean bee-pollinated phrygana plants [64].

High-quality pollen is an additional reward that is crucial for insect pollinators and is offered by complex flowers. The quality of pollen sources is determined by their amino acid constitution, protein content, and mineral composition [65]. Pollen varies from as low as $2.5 \%$ to $61 \%$ in the content of protein dry mass [66]. Size, longevity, and reproductive output of pollinators [67-69], as well as the health of entire bee colonies, depend on the quality and quantity of pollen received [70-73]. Bees are known to assess pollen amounts and properties and prefer pollen-rich flowers [74-77].

It has been hypothesized that complex pollen-rewarding and buzz-pollinated flowers produce better-quality pollen that attracts their pollinators [78,79]. In a study with 377 plant species from 93 families, buzz-pollinated clades contained pollen grains rich in protein content compared to the other clades [79]. A study that examined foraging preferences and diet breadth of bumblebees in the southern UK found that they preferred pollen of Fabaceae members compared to that of simpler inflorescences of Asteraceae [80]. It is likely that pollen of Fabaceae species is richer in its protein content compared to Asteraceae pollen, due to their symbiosis with nitrogen-fixing bacteria [81,82].

\section{Perception and Processing of Floral Complexity Signals}

Detection and discrimination of flowers is of critical importance for insects that depend on their food (and various other) rewards. Pollinators combine odor and visual information to accomplish this task. While we know various aspects of insect visual systems in great detail, particularly that of honeybees, it is still unclear how they perceive and integrate combinations of signals such as color, intensity, size, shape, pattern, and symmetry advertised by flowers. As morphologically complex flowers possess these myriad visual features, we do not yet fully understand how insects perceive 
these flowers. Below, we introduce key features of the visual system of bees as a well-studied model, and discuss some of the aspects pertaining to sensory perception of patterns and symmetry associated with complex flower shapes.

Most insects have compound eyes with a mosaic of optical units (ommatidia). Each ommatidium contains photoreceptor cells with photopigments, which capture the incoming photons. Photoreceptors are typically G-protein coupled receptors with an opsin protein and a chromophore, of which retinal is the most common. Light is absorbed by the chromophore, which in turn isomerizes, causing conformational change in the opsin. This results in a phototransduction cascade (see [83] and references therein for a general introduction). Insects exhibit a diverse array of photoreceptor cells, varying from three in honeybees to eight in Papilio spp. Photoreceptors that are sensitive in the long-wavelength region ("green" receptors) are the most common type in insect taxa that possess four receptors or more [84-86].

Bees typically possess a trichromatic visual system with photoreceptors that are sensitive in the UV, blue, and green regions [87]. Chromatic vision, required for perceiving color signals, is mainly achieved by neuronal comparison of signals (color-opponency) from all the three receptor types [88]. Achromatic vision, needed for detecting floral shapes, involves the long wavelength receptor alone $[89,90]$.

To extract information from visual features of flowers, insects utilize achromatic as well as chromatic information. The detection itself depends on the size and distance of the flower from the insect [89]. Typically, the insects need to be quite close to the flowers $(20-30 \mathrm{~cm})$, to recognize and resolve their visual features [91]. Characteristics of the flowers such as color, shape, and size, along with the insect's structure of the eye, inter-ommatidial angle, and angular size of photoreceptor fields affect visual acuity [92].

Depending on the visual system of the insect, the flower needs to be projected on its eye in a way that a critical number of ommatidia receive a sufficient signal for excitation. This number of ommatidia depends on the intensity of the contrast provided by the flower against the background. For flowers without such green contrast (such as flowers within dense inflorescences), the number of ommatidia required is much larger [89]. Therefore, understanding how color contrast to the background interacts with detection of patterns presented by flowers is significant. Honeybees trained to a bilaterally symmetrical flower of three different colors, and tested with different angular orientations of the same, performed better with decreasing color distance to the background (perceptual difference). To explain this finding, a hierarchical system was suggested, where recognition of color precedes pattern recognition. Consequently, with increasing color contrast to the background, the processing of floral color takes precedence and the accuracy to perceive patterns declines [93].

After perceiving floral shapes, pollinators associate them with food rewards. Behavioral experiments indicated an innate preference for bilateral symmetry in honeybees [94]. However, a later study suggested that these preferences could have resulted from the pre-training procedure used in the experiment [95]. Early work showed that honeybees trained to relatively simple radial models preferred complex disruptive patterns in choice tests. When trained to complex patterns, they showed increased response to such patterns. In later experiments, honeybees were trained to discriminate bilaterally symmetric from non-symmetric patterns, and also transferred this discrimination to novel patterns $[96,97]$. Bumblebees preferentially visited cone-like and tubular shapes compared to flat models [98-100], while in honeybees no such significant preference for depth was recorded [101]. These findings confirm earlier field observations that zygomorphic flowers were visited relatively more by bumblebees than by honeybees [102].

These behavioral studies indicate that elements of floral complexity, such as bilateral symmetry, are easily recognized and learned by insect pollinators. Features such as shape and patterns have been debated to be recognized using either retinotopic snapshots (template hypothesis [93]) or by extracting important image features (pattern hypothesis [103]). Some features known to be extracted by bees include contour lengths, their densities, and the area occupied by pattern [104]. Currently, a conceptual framework that integrates both hypotheses is widely accepted, where extracted features are combined into an ordered alignment for recognizing flowers $[105,106]$. Additionally, symmetry 
detectors in the neuronal systems of flower-visiting insects have been suggested (e.g., [96,103,104,107]). As flowers with different symmetries vary in their contrasts of the boundaries, mechanisms used to detect radial symmetry might differ from those used to identify bilateral symmetry [103]. Based on behavioral experiments in Apis mellifera, Srinivasan and colleagues suggest the use of geometrical cues to differentiate orientation of patterns such as stripes and checkerboards [107]. This was proposed to indicate the presence of three channels that are sensitive to different orientations and possibly separated by 120 degrees from each other, due to the ommatidial hexagonal arrangement. Cells that function to detect lines and edges are also known to be present in insects, and help to detect global and local features of objects [108,109].

The importance of the position of objects within the visual field for pattern recognition has been demonstrated in various insects [110-112]. By training bees to varying inclinations of black and white contrasting pattern, the lower part of the frontal visual field was elegantly demonstrated as crucial for pattern recognition [112]. This also endorses the presence of "space-constant fibres" in the optic ganglia of bee eyes, which are sensitive to spatial directions [113].

In conclusion, features of floral complexity are perceived by the visual system of insects, based mostly on excitation of long-wavelength color receptors in the lower part of the field of vision. Bees readily learn to associate these features with food rewards. Several neural mechanisms were suggested to underlie the learning process, but have not yet been experimentally confirmed.

\section{Learning to Handle Complex Flowers}

Flowers with complex morphologies are learned more slowly than simple flowers [114]. Handling and travel times increase when bees forage on more than one type of flower at the same time, especially if flowers are complex [4,115-117]. Yet once learned, flower-handling techniques are retained in memory for days or even weeks $[118,119]$. Thus, new complex flower types are initially less profitable to foraging bees than familiar or simple flowers with the same reward. Nevertheless, new complex flowers become more profitable if bees persist and learn how to handle them, resulting in greatly reduced handling times and higher food intake rates. This is because a much larger improvement in handling proficiency is expected for complex flowers than for simple ones [114].

Energy intake rate (calories ingested/time) is a popular currency for evaluating foraging efficiency [120]. Alternatively, the ratio between energy intake and expenditure can provide a measure of foraging success [121]. The handling of new, complex flowers by pollinators is inefficient by both currencies, since it requires more time and energy than the handling of simple sources. From a foraging perspective, this raises questions about the cognitive and behavioral mechanisms that cause animals to persevere on complex food sources until they have learned to handle them effectively.

In an ongoing research project, we are exploring mechanisms that may allow bumblebees to learn complex tasks in spite of initially low rewards in the presence of alternatives. We are considering the following hypotheses to explain how bumblebees may accept complex flowers with high future but low immediate rewards, even in competition with simple flowers with moderate amounts of immediate rewards:

Hypothesis 1. Bumblebees may use their speed of improvement in reward intake, in addition to the mean recent intake rates, to anticipate the future profitability of complex flowers. In other words, rapid improvement in the handling of complex flowers may reinforce the bees' attempts to visit such flowers. This strategy could cause bees to persist on resources that require long handling times initially, but that are highly profitable to experienced foragers. During initial learning, the low intake rate from these flowers may be compensated by the high improvement rate, and bees could rate such flowers as high-potential. After bees learn to handle the complex flowers, the reward intake rate would increase, while the improvement rate would decrease.

Hypothesis 2. Bumblebees may use the amount or quality of food collected, separately from the costs of handling a flower, to evaluate the potential profitability of morphologically complex flowers. Handling times may enter 
into flower choice independently. Thus, inexperienced bees could evaluate high-reward complex flowers as low on intake rates, but high on reward amount. This provides an indication that potential reward rates are high if handling time can be shortened. Experienced foragers would score such flowers higher on recent intake rates, while their evaluation in terms of reward volume would remain unchanged. Choices of honeybees between food sources that differ both in rewards and handling times are consistent with a separate evaluation of each parameter [122,123].

Hypothesis 3. Once a bee has experienced a higher reward rate on a complex flower, this may prime a preference for complex flowers generally in future encounters. Individual sampling behavior may be of sufficient frequency that some bees will discover how to handle complex flowers. If experience can create a bias towards complex morphology, this may enable some bees to exploit additional rewarding complex flowers in their habitat.

Experiments to test these hypotheses combine exposure of bumblebees to real and artificial flowers of varying morphological complexity. We aim to manipulate, independently, the flowers' initial and steady-state handling times, their rewards, and the bees' previous foraging experience, to assess whether and how these putative mechanisms interact to explain learning of complex morphologies.

\section{Conclusions and Future Directions}

Floral morphological complexity is an important dimension for interpreting the evolution of plant-pollinator interactions. To understand the persistence and spread of floral complexity in angiosperms, the sensory signals associated with complex morphologies should be identified. Complex structures appear to occur together with other floral signals and cues to enhance the attraction of complex flowers to pollinators, and function as a sieve favoring interacting insects with specific traits that aid pollination efficiency. Of the many hypotheses that have been put forward to explain the evolution of complexity, efficient pollen receipt has received considerable support. Recent molecular advances in our understanding of flower-shape evolution and of insect sensory capabilities provide clues as to the origins of complexity. Ongoing work investigates potential learning mechanisms that could induce pollinators to visit complex flowers despite their low initial foraging profitability. From a sensory physiology perspective, the coding of the behavioral repertoire necessary for extracting rewards from complex flowers is a significant aspect to unravel. We propose that developing quantitative measures to score and compare floral complexity among species (see [6,8] for promising approaches), is an additional important direction for future research.

Author Contributions: T.K. conceived this review. S.K. and T.K. wrote the manuscript.

Funding: This study was funded by grant \#250/16 from the Israel Science Foundation to Tamar Keasar. Shivani Krishna is a post-doctoral fellow supported by the grant.

Acknowledgments: Simcha Lev-Yadun commented on the manuscript.

Conflicts of Interest: The authors declare no conflict of interest.

\section{References}

1. Frame, D.; Durou, S. Morphology and biology of Napoleonaea vogelii (Lecythidaceae) flowers in relation to the natural history of insect visitors. Biotropica 2001, 33, 458-471. [CrossRef]

2. Heinrich, B. "Majoring" and "minoring" by foraging bumblebees, Bombus vagans: An experimental analysis. Ecology 1979, 60, 245-255. [CrossRef]

3. Laverty, T.M. The flower-visiting behaviour of bumble bees: Floral complexity and learning. Can. J. Zool. 1980, 58, 1324-1335. [CrossRef]

4. Laverty, T.M. Bumble bee learning and flower morphology. Anim. Behav. 1994, 47, 531-545. [CrossRef]

5. Neal, P.R.; Dafni, A.; Giurfa, M. Floral symmetry and its role in plant-pollinator systems: Terminology, distribution, and hypotheses. Annu. Rev. Ecol. Syst. 1998, 29, 345-373. [CrossRef] 
6. Kaiser-Bunbury, C.N.; Vázquez, D.P.; Stang, M.; Ghazoul, J. Determinants of the microstructure of plant-pollinator networks. Ecology 2014, 95, 3314-3324. [CrossRef]

7. Muth, F.; Keasar, T.; Dornhaus, A. Trading off short-term costs for long-term gains: How do bumblebees decide to learn morphologically complex flowers? Anim. Behav. 2015, 101, 191-199. [CrossRef]

8. Stefanaki, A.; Kantsa, A.; Tscheulin, T.; Charitonidou, M.; Petanidou, T. Lessons from red data books: Plant vulnerability increases with floral complexity. PLoS ONE 2015, 10, e0138414. [CrossRef] [PubMed]

9. Endress, P.K. Evolution of floral symmetry. Curr. Opin. Plant Biol. 2001, 4, 86-91. [CrossRef]

10. Endress, P.K. Evolutionary diversification of the flowers in angiosperms. Am. J. Bot. 2011, 98, 370-396. [CrossRef] [PubMed]

11. Westerkamp, C. Keel blossoms: Bee flowers with adaptations against bees. Flora 1997, 192, $125-132$. [CrossRef]

12. Westerkamp, C.; Claßen-Bockhoff, R. Bilabiate flowers: The ultimate response to bees? Ann. Bot. 2007, 100, 361-374. [CrossRef] [PubMed]

13. Endress, P.K. The immense diversity of floral monosymmetry and asymmetry across angiosperms. Bot. Rev. 2012, 78, 345-397. [CrossRef]

14. Hileman, L.C. Trends in flower symmetry evolution revealed through phylogenetic and developmental genetic advances. Philos. Trans. R. Soc. Lond. B Biol. Sci. 2014, 369. [CrossRef] [PubMed]

15. Berg, R. The ecological significance of correlation pleiades. Evolution 1960, 14, 171-180. [CrossRef]

16. Harder, L.D.; Johnson, S.D. Darwin's beautiful contrivances: Evolutionary and functional evidence for floral adaptation. New Phytol. 2009, 183, 530-545. [CrossRef] [PubMed]

17. De Luca, P.A.; Vallejo-Marín, M. What's the 'buzz'about? The ecology and evolutionary significance of buzz-pollination. Curr. Opin. Plant Biol. 2013, 16, 429-435. [CrossRef] [PubMed]

18. Morgan, T.; Whitehorn, P.; Lye, G.C.; Vallejo-Marín, M. Floral sonication is an innate behaviour in bumblebees that can be fine-tuned with experience in manipulating flowers. J. Insect Behav. 2016, 29, 233-241. [CrossRef] [PubMed]

19. Stebbins, G.L. Natural selection and the differentiation of angiosperm families. Evolution 1951, 5, $299-324$. [CrossRef]

20. Leonard, A.S.; Dornhaus, A.; Papaj, D.R. Flowers help bees cope with uncertainty: Signal detection and the function of floral complexity. J. Exp. Biol. 2011, 214, 113-121. [CrossRef] [PubMed]

21. Russell, A.L.; Mauerman, K.B.; Golden, R.E.; Papaj, D.R. Linking components of complex signals to morphological part: The role of anther and corolla in the complex floral display. Anim. Behav. 2018, 135, 223-236. [CrossRef]

22. Renner, S.S. Rewardless flowers in the angiosperms and the role of insect cognition in their evolution. In Plant-Pollinator Interactions: From Specialization to Generalization; University of Chicago Press: Chicago, IL, USA, 2006; pp. 123-144.

23. Zhang, J.; Tian, Y.; Wang, L.; He, C. Functional evolutionary developmental biology (evo-devo) of morphological novelties in plants. J. Syst. Evol. 2010, 48, 94-101. [CrossRef]

24. Gaskett, A. Orchid pollination by sexual deception: Pollinator perspectives. Biol. Rev. 2011, 86, 33-75. [CrossRef] [PubMed]

25. Binkenstein, J.; Stang, M.; Renoult, J.P.; Schaefer, H.M. Weak correlation of flower color and nectar-tube depth in temperate grasslands. J. Plant Ecol. 2016, 10, 397-405. [CrossRef]

26. Menzel, R.; Shmida, A. The ecology of flower colours and the natural colour vision of insect pollinators: The Israeli flora as a study case. Biol. Rev. 1993, 68, 81-120. [CrossRef]

27. Dukas, R.; Shmida, A. Correlation between the color, size and shape of Israeli crucifer flowers and relationships to pollinators. Oikos 1989, 54, 281-286. [CrossRef]

28. Hodges, S.A.; Whittall, J.B.; Fulton, M.; Yang, J.Y. Genetics of floral traits influencing reproductive isolation between Aquilegia formosa and Aquilegia pubescens. Am. Nat. 2002, 159, S51-S60. [CrossRef] [PubMed]

29. Galen, C.; Zimmer, K.A.; Newport, M.E. Pollination in floral scent morphs of Polemonium viscosum: A mechanism for disruptive selection on flower size. Evolution 1987, 41, 599-606. [PubMed]

30. Vallejo-Marín, M.; Da Silva, E.M.; Sargent, R.D.; Barrett, S.C. Trait correlates and functional significance of heteranthery in flowering plants. New Phytol. 2010, 188, 418-425. [CrossRef] [PubMed]

31. Buchmann, S. Buzz pollination in angiosperms. In Handbook of Experimental Pollination Biology; Jones, C.E., Little, R.J., Eds.; Van Nostrand Reinhold: New York, NY, USA, 1983; pp. 73-113. 
32. Stebbins, G.L. Flowering Plants: Evolution above the Species Level; Arnold: London, UK, 1974.

33. Crepet, W.L. Timing in the evolution of derived floral characters: Upper Cretaceous (Turonian) taxa with tricolpate and tricolpate-derived pollen. Rev. Palaeobot. Palynol. 1996, 90, 339-359. [CrossRef]

34. Donoghue, M.J.; Ree, R.H.; Baum, D.A. Phylogeny and the evolution of flower symmetry in the Asteridae. Trends Plant Sci. 1998, 3, 311-317. [CrossRef]

35. Endress, P.K. Symmetry in flowers: Diversity and evolution. Int. J. Plant Sci. 1999, 160, S3-S23. [CrossRef] [PubMed]

36. Sargent, R.D. Floral symmetry affects speciation rates in angiosperms. Proc. R. Soc. Lond. B Biol. Sci. 2004, 271, 603-608. [CrossRef] [PubMed]

37. Fenster, C.B.; Armbruster, W.S.; Wilson, P.; Dudash, M.R.; Thomson, J.D. Pollination syndromes and floral specialization. Annu. Rev. Ecol. Evol. Syst. 2004, 35, 375-403. [CrossRef]

38. Kay, K.M.; Sargent, R.D. The role of animal pollination in plant speciation: Integrating ecology, geography, and genetics. Annu. Rev. Ecol. Evol. Syst. 2009, 40, 637-656. [CrossRef]

39. Citerne, H.; Jabbour, F.; Nadot, S.; Damerval, C. The evolution of floral symmetry. Adv. Bot. Res. 2010, 54, 85-137.

40. Vamosi, J.C.; Vamosi, S.M. Zygomorphy, Area, and the Latitudinal Biodiversity Gradient in Angiosperms. In Evolution of Plant-Pollinator Relationships; Patiny, S., Ed.; Cambridge University Press: Cambridge, UK, 2012; pp. 320-343.

41. Zhao, Y.; Ren, Z.; Lázaro, A.; Wang, H.; Bernhardt, P.; Li, H.; Li, D. Floral traits influence pollen vectors' choices in higher elevation communities in the Himalaya-Hengduan Mountains. BMC Ecol. 2016, 16, 26. [CrossRef] [PubMed]

42. Lázaro, A.; Jakobsson, A.; Totland, Ø. How do pollinator visitation rate and seed set relate to species' floral traits and community context? Oecologia 2013, 173, 881-893. [CrossRef] [PubMed]

43. Stang, M.; Klinkhamer, P.G.; Van der Meijden, E. Asymmetric specialization and extinction risk in plant-flower visitor webs: A matter of morphology or abundance? Oecologia 2007, 151, 442-453. [CrossRef] [PubMed]

44. Benadi, G.; Hovestadt, T.; Poethke, H.; Blüthgen, N. Specialization and phenological synchrony of plant-pollinator interactions along an altitudinal gradient. J. Anim. Ecol. 2014, 83, 639-650. [CrossRef] [PubMed]

45. Olesen, J.M.; Dupont, Y.L.; Ehlers, B.K.; Hansen, D.M. The openness of a flower and its number of flower-visitor species. Taxon 2007, 56, 729-736. [CrossRef]

46. Watts, S.; Dormann, C.F.; Martín González, A.M.; Ollerton, J. The influence of floral traits on specialization and modularity of plant-pollinator networks in a biodiversity hotspot in the Peruvian Andes. Ann. Bot. 2016, 118, 415-429. [CrossRef] [PubMed]

47. McCall, C.; Primack, R.B. Influence of flower characteristics, weather, time of day, and season on insect visitation rates in three plant communities. Am. J. Bot. 1992, 79, 434-442. [CrossRef]

48. Saleh, N.; Ohashi, K.; Thomson, J.D.; Chittka, L. Facultative use of the repellent scent mark in foraging bumblebees: Complex versus simple flowers. Anim. Behav. 2006, 71, 847-854. [CrossRef]

49. Hegland, S.J.; Totland, Ø. Relationships between species' floral traits and pollinator visitation in a temperate grassland. Oecologia 2005, 145, 586-594. [CrossRef] [PubMed]

50. Ohashi, K. Consequence of floral complexity for bumblebee-mediated geitonogamous self-pollination in Salvia nipponica Miq. (Labiatae). Evolution 2002, 56, 2414-2423. [PubMed]

51. Pellissier, L.; Pottier, J.; Vittoz, P.; Dubuis, A.; Guisan, A. Spatial pattern of floral morphology: Possible insight into the effects of pollinators on plant distributions. Oikos 2010, 119, 1805-1813. [CrossRef]

52. Fantinato, E.; Giovanetti, M.; Del Vecchio, S.; Buffa, G. Altitudinal patterns of floral morphologies in dry calcareous grasslands. Plant Sociol. 2016, 53, 83-90.

53. Rodríguez-Gironés, M.A.; Santamaría, L. Resource competition, character displacement, and the evolution of deep corolla tubes. Am. Nat. 2007, 170, 455-464. [CrossRef] [PubMed]

54. Montgomery, B.R.; Rathcke, B.J. Effects of floral restrictiveness and stigma size on heterospecific pollen receipt in a prairie community. Oecologia 2012, 168, 449-458. [CrossRef] [PubMed]

55. McLernon, S.M.; Murphy, S.D.; Aarssen, L.W. Heterospecific pollen transfer between sympatric species in a midsuccessional old-field community. Am. J. Bot. 1996, 83, 1168-1174. [CrossRef] 
56. Arceo-Gómez, G.; Abdala-Roberts, L.; Jankowiak, A.; Kohler, C.; Meindl, G.A.; Navarro-Fernández, C.M.; Parra-Tabla, V.; Ashman, T.; Alonso, C. Patterns of among-and within-species variation in heterospecific pollen receipt: The importance of ecological generalization. Am. J. Bot. 2016, 103, 396-407. [CrossRef] [PubMed]

57. Stout, J.C.; Allen, J.A.; Goulson, D. The influence of relative plant density and floral morphological complexity on the behaviour of bumblebees. Oecologia 1998, 117, 543-550. [CrossRef] [PubMed]

58. Culbert, B.M.; Forrest, J.R. Floral symmetry affects bumblebee approach consistency in artificial flowers. J. Pollinat. Ecol. 2016, 18, 1-6.

59. Cohen, D.; Shmida, A. The evolution of flower display and reward. In Evolutionary Biology; Hecht, M.K., MacIntyre, R.J., Clegg, M.T., Eds.; Springer: New York, NY, USA, 1993; Volume 27, pp. 197-243.

60. Warren, J.; Diaz, A. A two-pollinator model for the evolution of floral complexity. Evol. Ecol. 2001, 15, 157-166. [CrossRef]

61. Harder, L.; Cruzan, M. An evaluation of the physiological and evolutionary influences of inflorescence size and flower depth on nectar production. Funct. Ecol. 1990, 4, 559-572. [CrossRef]

62. Ornelas, J.; Ordano, M.; De-Nova, A.J.; Quintero, M.; Garland, T. Phylogenetic analysis of interspecific variation in nectar of hummingbird-visited plants. J. Evol. Biol. 2007, 20, 1904-1917. [CrossRef] [PubMed]

63. Tavares, D.C.; Freitas, L.; Gaglianone, M.C. Nectar volume is positively correlated with flower size in hummingbird-visited flowers in the Brazilian Atlantic Forest. J. Trop. Ecol. 2016, 32, 335-339. [CrossRef]

64. Petanidou, T.; Smets, E. The potential of marginal lands for bees and apiculture: Nectar secretion in Mediterranean shrublands. Apidologie 1995, 26, 39-52. [CrossRef]

65. Levin, M.; Haydak, M. Comparative value of different pollens in the nutrition of Osmia lignaria. Bee World 1957, 38, 221-226. [CrossRef]

66. Buchmann, S.L. Vibratile pollination in Solanum and Lycopersicon: A look at pollen chemistry. In Solanaceae: Biology and Systematics; D’Arcy, W.G., Ed.; Columbia University Press: New York, NY, USA, 1986; pp. 237-252.

67. Greenberg, L. Year-round culturing and productivity of a sweat bee, Lasioglossum zephyrum (Hymenoptera: Halictidae). J. Kans. Entomol. Soc. 1982, 55, 13-22.

68. Schmidt, J.O.; Thoenes, S.C.; Levin, M.D. Survival of honey bees, Apis mellifera (Hymenoptera: Apidae), fed various pollen sources. Ann. Entomol. Soc. Am. 1987, 80, 176-183. [CrossRef]

69. Regali, A.; Rasmont, P. Nouvelles méthodes de test pour l'évaluation du régime alimentaire chez des colonies orphelines de Bombus terrestris (L) (Hymenoptera, Apidae). Apidologie 1995, 26, 273-281. [CrossRef]

70. Plowright, R.; Pendrel, B. Larval growth in bumble bees (Hymenoptera: Apidae). Can. Entomol. 1977, 109, 967-973. [CrossRef]

71. Ribeiro, M. Growth in bumble bee larvae: Relation between development time, mass, and amount of pollen ingested. Can. J. Zool. 1994, 72, 1978-1985. [CrossRef]

72. Génissel, A.; Aupinel, P.; Bressac, C.; Tasei, J.; Chevrier, C. Influence of pollen origin on performance of Bombus terrestris micro-colonies. Entomol. Exp. Appl. 2002, 104, 329-336. [CrossRef]

73. Tasei, J.; Aupinel, P. Nutritive value of 15 single pollens and pollen mixes tested on larvae produced by bumblebee workers (Bombus terrestris, Hymenoptera: Apidae). Apidologie 2008, 39, 397-409. [CrossRef]

74. Dobson, H.E. Survey of pollen and pollenkitt lipids-Chemical cues to flower visitors? Am. J. Bot. 1988, 170-182. [CrossRef]

75. Buchmann, S.L.; Cane, J.H. Bees assess pollen returns while sonicating Solanum flowers. Oecologia 1989, 81, 289-294. [CrossRef] [PubMed]

76. Gori, D.F. Floral color change in Lupinus argenteus (Fabaceae): Why should plants advertise the location of unrewarding flowers to pollinators? Evolution 1989, 43, 870-881. [CrossRef] [PubMed]

77. Harder, L.D. Behavioral responses by bumble bees to variation in pollen availability. Oecologia 1990, 85, 41-47. [CrossRef] [PubMed]

78. Simpson, B.B.; Neff, J.L. Evolution and diversity of floral rewards. In Handbook of Experimental Pollination Biology; Jones, C.E., Little, R.J., Eds.; Van Nostrand Reinhold: New York, NY, USA, 1983; pp. 142-159.

79. Roulston, T.H.; Cane, J.H.; Buchmann, S.L. What governs protein content of pollen: Pollinator preferences, pollen-pistil interactions, or phylogeny? Ecol. Monogr. 2000, 70, 617-643.

80. Goulson, D.; Darvill, B. Niche overlap and diet breadth in bumblebees; are rare species more specialized in their choice of flowers? Apidologie 2004, 35, 55-63. [CrossRef] 
81. Goulson, D. Bumblebees. In Silent Summer: The State of Wildlife in Britain and Ireland; Maclean, N., Ed.; Cambridge University Press: Cambridge, UK, 2010; pp. 415-429.

82. Forcone, A.; Aloisi, P.V.; Ruppel, S.; Muñoz, M. Botanical composition and protein content of pollen collected by Apis mellifera L. in the north-west of Santa Cruz (Argentinean Patagonia). Grana 2011, 50, 30-39. [CrossRef]

83. Cronin, T.W.; Johnsen, S.; Marshall, N.J.; Warrant, E.J. Visual Ecology; Princeton University Press: Princeton, NJ, USA, 2014.

84. Menzel, R.; Blakers, M. Colour receptors in the bee eye-Morphology and spectral sensitivity. J. Comp. Physiol. A 1976, 108, 11-13. [CrossRef]

85. Peitsch, D.; Fietz, A.; Hertel, H.; de Souza, J.; Ventura, D.F.; Menzel, R. The spectral input systems of hymenopteran insects and their receptor-based colour vision. J. Comp. Physiol. A 1992, 170, 23-40. [CrossRef] [PubMed]

86. Kinoshita, M.; Shimada, N.; Arikawa, K. Colour vision of the foraging swallowtail butterfly Papilio xuthus. J. Exp. Biol. 1999, 202, 95-102. [PubMed]

87. Daumer, K. Reizmetrische untersuchung des Farbensehens der Bienen. Z. Vergl. Physiol. 1956, 38, 413-478.

88. Backhaus, W. Color opponent coding in the visual system of the honeybee. Vis. Res. 1991, 31, $1381-1397$. [CrossRef]

89. Giurfa, M.; Vorobyev, M.; Kevan, P.; Menzel, R. Detection of coloured stimuli by honeybees: Minimum visual angles and receptor specific contrasts. J. Comp. Physiol. A 1996, 178, 699-709. [CrossRef]

90. Giurfa, M.; Vorobyev, M.; Brandt, R.; Posner, B.; Menzel, R. Discrimination of coloured stimuli by honeybees: Alternative use of achromatic and chromatic signals. J. Comp. Physiol. A 1997, 180, 235-243. [CrossRef]

91. Ne'eman, G.; Ne'eman, R. Factors determining visual detection distance to real flowers by Bumble bees. J. Pollinat. Ecol. 2017, 20,1-12.

92. Land, M.F. Visual acuity in insects. Annu. Rev. Entomol. 1997, 42, 147-177. [CrossRef] [PubMed]

93. Giurfa, M.; Backhaus, W.; Menzel, R. Color and angular orientation in the discrimination of bilateral symmetric patterns in the honeybee. Naturwissenschaften 1995, 82, 198-201. [CrossRef]

94. Rodríguez, I.; Gumbert, A.; de Ibarra, N.H.; Kunze, J.; Giurfa, M. Symmetry is in the eye of the 'beeholder': Innate preference for bilateral symmetry in flower-naïve bumblebees. Naturwissenschaften 2004, 91, 374-377. [CrossRef] [PubMed]

95. Plowright, C.; Evans, S.; Leung, J.C.; Collin, C. The preference for symmetry in flower-naïve and not-so-naïve bumblebees. Learn. Motiv. 2011, 42, 76-83. [CrossRef]

96. Horridge, G.A. The honeybee (Apis mellifera) detects bilateral symmetry and discriminates its axis. J. Insect Physiol. 1996, 42, 755-764. [CrossRef]

97. Giurfa, M.; Eichmann, B.; Menzel, R. Symmetry perception in an insect. Nature 1996, 382, 458. [CrossRef] [PubMed]

98. Kugler, H. Die Ausnützung der Saftmalsumfärbung bei der Roßkastanie durch Bienen und Hummeln. Ber. Dtsch. Bot. Ges. 1936, 54, 394-400.

99. Kugler, H. Hummeln als Blütenbesucher: Ein Beitrag zur experimentellen Blütenkologie. Naturwissenschaften 1943, 19, 143-323.

100. Manning, A. The effect of honey-guides. Behaviour 1956, 9, 114-139. [CrossRef]

101. Free, J. Effect of flower shapes and nectar guides on the behaviour of foraging honeybees. Behaviour 1970, 37, 269-285. [CrossRef]

102. Leppik, E. The ability of insects to distinguish number. Am. Nat. 1953, 87, 229-236. [CrossRef]

103. Giurfa, M.; Dafni, A.; Neal, P.R. Floral symmetry and its role in plant-pollinator systems. Int. J. Plant Sci. 1999, 160, S41-S50. [CrossRef] [PubMed]

104. Zhang, S.; Srinivasan, M. Prior experience enhances pattern discrimination in insect vision. Nature 1994, 368, 330. [CrossRef]

105. Dyer, A.G.; Griffiths, D.W. Seeing near and seeing far; behavioural evidence for dual mechanisms of pattern vision in the honeybee (Apis mellifera). J. Exp. Biol. 2012, 215, 397-404. [CrossRef] [PubMed]

106. Avarguès-Weber, A.; d'Amaro, D.; Metzler, M.; Dyer, A.G. Conceptualization of relative size by honeybees. Front. Neurosci. 2014, 8, 80 .

107. Srinivasan, M.V.; Zhang, S.; Rolfe, B. Is pattern vision in insects mediated by 'cortical' processing? Nature 1993, 362, 539. [CrossRef]

108. O'Carroll, D. Feature-detecting neurons in dragonflies. Nature 1993, 362, 541. [CrossRef] 
109. Osorio, D. Symmetry detection by categorization of spatial phase, a model. Proc. R. Soc. Lond. B 1996, 263, 105-110. [CrossRef]

110. Collett, T.; Blest, A. Binocular, directionally selective neurones, possibly involved in the optomotor response of insects. Nature 1966, 212, 1330-1333. [CrossRef] [PubMed]

111. Collett, T. Centripetal and centrifugal visual cells in medulla of the insect optic lobe. J. Neurophysiol. 1970, 33, 239-256. [CrossRef] [PubMed]

112. Wehner, R. Pattern modulation and pattern detection in the visual system of Hymenoptera. In Information Processing in the Visual Systems of Anthropods; Wehner, R., Ed.; Springer: Berlin, Germany, 1972; pp. 183-194.

113. Lindauer, M.; Nedel, J.O. Ein Schweresinnesorgan der Honigbiene. Z. Vergl. Physiol. 1959, 42, $334-364$. [CrossRef]

114. Gegear, R.J.; Laverty, T.M. Effect of flower complexity on relearning flower-handling skills in bumble bees. Can. J. Zool. 1995, 73, 2052-2058. [CrossRef]

115. Woodward, G.L.; Laverty, T.M. Recall of flower handling skills by bumble bees: A test of Darwin's interference hypothesis. Anim. Behav. 1992, 44, 1045-1051. [CrossRef]

116. Chittka, L.; Thomson, J.D. Sensori-motor learning and its relevance for task specialization in bumble bees. Behav. Ecol. Sociobiol. 1997, 41, 385-398. [CrossRef]

117. Gegear, R.; Laverty, T. How many flower types can bumble bees work at the same time? Can. J. Zool. 1998, 76, 1358-1365. [CrossRef]

118. Keasar, T.; Motro, U.; Shur, Y.; Shmida, A. Overnight memory retention of foraging skills by bumblebees is imperfect. Anim. Behav. 1996, 52, 95-104. [CrossRef]

119. Chittka, L. Sensorimotor learning in bumblebees: Long-term retention and reversal training. J. Exp. Biol. 1998, 201, 515-524.

120. Stephens, D.W.; Brown, J.S.; Ydenberg, R.C. Foraging: Behavior and Ecology; University of Chicago Press: Chicago, IL, USA, 2007.

121. Charlton, N.L.; Houston, A.I. What currency do bumble bees maximize? PLoS ONE 2010, 5, e12186. [CrossRef] [PubMed]

122. Shafir, S. Intransitivity of preferences in honey bees: Support for 'comparative' evaluation of foraging options. Anim. Behav. 1994, 48, 55-67. [CrossRef]

123. Sanderson, C.E.; Orozco, B.S.; Hill, P.S.; Wells, H. Honeybee (Apis mellifera ligustica) response to differences in handling time, rewards and flower colours. Ethology 2006, 112, 937-946. [CrossRef] 